or globular massiveness) against chance dislodgement. Cravenechinus is, so far as I know, the only one of them that seems to have chosen an environment similar to that frequented by the more advanced Echinidae of the present day. But while very " modern" in its general appearance, it was more extraordinary in its intimate structure than any of its notoriously strange contemporaries.

\title{
REFERENCES
}

Jackson, R. T., 1912. Phylogeny of the Echini. Mem. Soc. Nat. Hist., Boston, vol. vii.

Mortensen, TH., 1940. A Monograph of the Echinoidea, vol. iii, pt. 1. Copenhagen.

\section{EXPLANATION OF PLATE}

Untouched photograph of Cravenechinus uniserialis gen, et sp. nov., Carboniferous Limestone, nr. Skipton, Yorks. (Brit. Mus. Geol. Dept. E. 32370.) $\times 5 \frac{1}{2}$ approx. Compare with Text-fig. 1, p. 193.

\section{CORRESPONDENCE}

\section{THE CORNISH MICA-TRAP PROBLEM COMPARED WITH A SEQUENCE OF ROCKS IN MALAYA}

SIR,-One of the unsettled problems of Cornish geology is the age of the mica-traps, or minettes, relative to the elvans, or quartz-porphyries and felsites. Which came first ? The general opinion is that the micatraps came last. For instance H. C. Versey $(1929$, p. 314) says : "The mica-lamprophyre dykes are probably of slightly later age." This opinion is based on the resemblance of the mica-traps to some exceptional rocks found among the Exeter Traps intercalated with sediments believed to be of Permian age and intrusive into Culm (Ussher and Teall, 1902). On the other hand, J. H. Collins and J. B. Hill did not hold that view. Collins $(1884$, p. 197) in a description of the Cornish mica-traps wrote : "A little farther to the west, in Gloweth Farm (near Truro), a series of pits on the south side of the turnpike road marks the position of another vein. This passes through Liskes in a N.N.E. direction to Boscolla, where it is intersected by one of the ordinary felspar-porphyries of the district." Hill (1906, p. 80) mentioned this record, but hesitated to accept it. In 1901, however, Hill evidently was of the opinion that the elvans came after the mica-traps (1901, pp. 32, 33, and 34). When I was a junior member of the Geological Survey in 1902 and 1903 in Cornwall the official view was that the mica-traps came last and I saw nothing to upset it. I am indebted to Mr. J. Robson of the Camborne School of Mines for telling me that no decisive evidence has been found in recent years.

My object in writing this letter is to point out that in Malaya very clear evidence has been found of granite being cut by lamprophyres and then by later acid rocks (1931, table on p. 47). Moreover, two months before leaving Malaya in May, 1931, I saw in the Bukit Ubi granite quarry, near Kuantan Town, granite cut by dolerite dykes, followed by dykes of quartz-porphyry cutting both the granite and the dolerite dykes. My record of this, however, was received with hesitation similar to that 
evinced by Hill towards Collins, therefore I decided to defer publication until someone confirmed it, which has been done by a member of the Geological Survey of Malaya, Mr. F. H. Fitch who was stationed in Kuantan and is now in England. He tells me there is no doubt of the sequence and that he has seen xenoliths of dolerite in a quartz-porphyry dyke. It does not follow of course that because a certain sequence of igneous rocks has been proved in Malaya a similar sequence must be accepted for Cornwall, roughly 8,000 miles away, without evidence equally clear ; but it must be conceded that Collins, who unfortunately was sometimes vague in differentiating between igneous rocks, may have been quite correct when he described a mica-trap as being intersected by a felspar-porphyry, and that he and Hill were right in considering the elvans later than the mica-traps.

Collins, J. H., 1884. The Geological Age of Central and West Cornwall. Journ. Royal Inst. Cornwall, viii, 162-205.

Hill, J. B., 1901. The Plutonic and other Intrusive Rocks of West Cornwall and their relation to the mineral ores. Trans. Royal Geol. Soc. Cornwall, xii, pt. vii.

1906. The Geology of Falmouth and Truro, etc. Mem. Geol. Surv. Great Britain. (Explanation of Sheet 352.)

SCrivenor, J. B., 1931. The Geology of Malaya. London.

Ussher, W. A. E., and J. J. H. Teall, 1902. The Geology of the Country Round Exeter. Mem. Geol. Surv. Great Britain. (Explanation of Sheet 325.)

VerSEY, H. C., 1929. Chapter 7 (Permian) in Handbook of the Geology of Great Britain, edited by J. W. Evans and C. J. Stubblefield. London.

68 Chaucer Road, J. B. Scrivenor.

BEDFORD.

20th May, 1946.

\section{THE CONCENTRATION OF MANGANESE ORES}

SIR,--In his Bulletin (1943) on the Geology of the Nsuta manganese ore deposits Mr. H. Service has shed much light on an occurrence whose economic importance has been no less than its scientific interest for some thirty years. The deeper working of the deposits appears to have demonstrated an original - or at any rate a geologically ancient-concentration of manganese ore in the Birrimian rocks. It is of interest to notice the similarity between the Birrimian rocks of Nsuta and those of Tassawini, Barama River, British Guiana, where a deposit of manganese ore has been described by Dr:D. A. Bryn-Davies.

The authors of an earlier paper (1930) were mainly concerned in 1926 with the superficially enriched ore which was then the principal product of the Nsuta mines. In suggesting that the importance of meteoric weather was overstressed by Bishopp and Hughes, Mr. Service has surely overlooked one of our more important arguments and does not appear to have adduced it in his own paper. I refer to the widespread occurrence and weathering of pyrites in the Birrimian rocks. We recorded the mineral in basic carbonate-talc-chlorite schist, as well as in the intrusive felspar-porphyries which are closely associated with the manganese orebodies; Service mentions its presence in the "Green Schists" and phyllites (pp. 13 and 14 of his work). 